\title{
Digital Space Analytics in Studying the Popularity of Microtourism Objects
}

\author{
Natalya V. Dmitrieva 1*[ORCID 0000-0002-8859-1671], \\ Galina V. Chistyakova 2[ORCID 0000-0002-2089-692X], \\ Irina V. Sandrakova 3[ORCID 0000-0001-7832-4847], \\ Tamara V. Frolova 1[ORCID 0000-0002-0817-4246], \\ Natalya Yu. Omarova 4[ORCID 0000-0003-0678-4590]
}

\author{
${ }^{1}$ Kemerovo State University, Kemerovo, Russia \\ ${ }^{2}$ Kemerovo State Medical University, Kemerovo, Russia \\ ${ }^{3}$ Novokuznetsk College of Mining and Transport named after V.F. Kuznetsova, Novokuznetsk, Russia \\ ${ }^{4}$ Yaroslav-the-Wise Novgorod State University, Veliky Novgorod, Russia \\ dmitrievanv@yandex.ru
}

\begin{abstract}
Since March 2020, against the backdrop of a massive decline in the global tourism market, there has been an increase in interest in micro-tourism in all countries - travelling within the region of residence or neighboring regions. The study is aimed at solving a serious problem of the development of micro-tourism, which consists in the lack of sufficient data on specific tourist sites of certain territories, as well as tools for their analysis, which make it possible to predict tourist flows, as well as to develop and promote both individual sites and the territory as a whole. Most of the existing approaches to analytics of the digital space in micro-tourism involve the use of data that tracks actions already taken by tourists, in most cases relying on their digital footprint associated with financial transactions. At the micro-tourism level, there are many tourist sites, the popularity of which cannot be analyzed in this way, for example, natural attractions. Using such digital space analytics tools as search queries and hashtags in social networks, the authors propose to assess the potential interest in tourist sites and their real popularity, to rank objects by these indicators and thus to predict tourist flows, distribute investments and highlight groups of objects for priority development. and promotion. The proposed approach has been tested on the example of a municipal district with thirteen tourist sites. It is inexpensive, understandable and convenient for specialists of any level of training. The ranking of tourist sites can be carried out both by tour operators and by municipal or regional authorities.
\end{abstract}

Keywords: microtourism, digital space, digital footprint, search query, hashtag, popularity of tourist objects, hospitality of territory

\section{INTRODUCTION}

The COVID-19 pandemic, on the one hand, negatively affected the development of the tourism business. Borders closure, fear of getting sick on foreign territory, falling incomes of the population and many other reasons led to a sharp reduction in the volume of the tourist market. Leisure and domestic tourism saw a sharp decline to 2.86 trillion US dollars, accounting for over $50 \%$ of revenue losses [1].
On the other hand, these prohibitions and challenges have led to the development of a segment of the so-called microtourism, which is a culture and travel market of trips of no more than 1000 kilometers from the place of residence. At the same time, consumers use all the services typical for longhaul tourism: accommodation, meals, leisure activities for curious tourists, symbolic purchases, participation in cultural and sports events [2]. The conducted studies confirm the growth in the number of tourists preferring local tourism [3]. Moreover, 
visits to places with a low tourist density are becoming especially popular [4].

One of the most important challenges in the development of microtourism is the lack of data that make it possible to assess and predict tourist flows on the scale of individual regions as well as municipal districts, small settlements and individual tourist attractions. This information is crucial for managing the hospitality of the territory forecasting tourist flows, developing programs for promoting the territory and individual tourist objects, evaluating the effectiveness of promotion.

Today most of the data used for analytics in all areas of business and science are digital in nature. The term digital space is widely used, which is most fully defined in [5] as a system of intellectual resources, information and data that provide interaction with the material world through cyberphysical systems and with individuals through digital technologies.

One of the types of data analysed for the tourism sector is passive mobile data, which is event data recorded by mobile network operators during consumer use of mobile phones connected to public voice and data networks. Passive mobile data allows for tourists to be identified, to detect patterns of temporal and spatial distribution, and to analyse spatial and temporal relationships. However, they do not allow correctly identifying tourism activities, in contrast to everyday or other non-tourist types of mobility [6].

Travel companies actively use smartphones [7] and digital applications [8] to develop local tourism. The research results show that the development of local tourism is actively influenced by social networks, as well [9]. In general, the use of the Internet is recognized as an effective strategy for promoting local tourism [10].

The possibilities of digital space analytics from the point of view of using the obtained data in microtourism is best documented in the work of $\mathrm{Z}$.Yu. Zhelnina [2]. The researcher distinguishes three groups of tools: a) financial corporations that keep records of millions of transactions; b) consulting corporations that accumulate native data and aggregate data from international ratings, competitiveness indices, etc.; c) owners of electronic platforms that operate with data on web search queries and real actions (orders) of users. This work reveals the possibilities of using data from the Sberindex laboratory, researches carried out by Mastercard Inc, Russian multimedia holding "RBC", the corporation "BusinesStat", the Agency for Strategic Initiatives under the Government of the Russian Federation, materials from the Russian Tour Operators Association, data from aggregators "Yandex", "Mail.Ru", "TUTU.Ru", as well as the information from specialized platforms that were generated from booking services. In most cases, these sources represent aggregated information that can be used for forecasting and strategic planning of the development of individual tourist destinations at the level of countries and regions. But few of the above can be used at the micro level, i. e. at the level of a municipal district, a small town or a single tourist object.

A more targeted approach to the analytics of digital space in microtourism is presented in the work of Chinese researchers who propose to analyze the spatial patterns of tourist flows based on tourists' digital footprint data collected from online travel diaries [11]. Unlike the work above, which relies only on online diaries, Spanish researchers suggest using three data sources to reflect various types of tourist activity in cities: Panoramio (sightseeing), Foursquare (consumption) and Twitter (being connected) [12].

Despite different approaches to the analytics of the digital space in microtourism, it is possible to identify a number of inherent problems that reduce the degree of efficiency of their use at the municipal district level, namely:

- most of the proposed tools are aimed at assessing the actions taken, and for managing the hospitality of a territory it is important to have the information about the potential of its development;

- some of the tools have lost their popularity or have already been eliminated, such as the Panoramio service, which was disabled by Google in November 2017;

- data from different sources are often inconsistent;

- there are not enough tools to assess the popularity of objects that do not involve financial costs to visit.

In the following parts of this paper, special attention is paid to those digital space analytics tools that allow for assessing the popularity of individual microtourism objects, including natural attractions, regardless of the financial activity of tourists when visiting these objects, as well as the degree of potential interest of tourists to a particular object. 


\section{MATERIALS AND METHODS}

The purpose of the study is to find digital space analytics tools that allow for assessing the popularity of microtourism objects on the example of a separate municipal district and making it possible to correlate the potential interest of tourists and the real popularity of objects.

To achieve this goal, the following tasks are consistently solved:

1) the potential interest of tourists to the objects of a particular municipal district is identified and analysed in dynamics through the statistics of search queries;

2) the real popularity of tourist objects is determined through the number of posts with the corresponding hashtags in the social network Instagram;

3) the ratings of potential interest and real popularity for each object are calculated;

4) the matrix of correlation of potential interest and real popularity of objects is developed; recommendations for each of the groups of objects are elaborated.

To collect and analyse the original data, the methods of analytic-synthetic processing of data set of open digital space, the simple ranking method, the method of developing a matrix information model are used. Possible methodological limitations include some rare cases of incorrect assessment of the popularity of an object through the number of hashtags used, which arise if there are some objects with the same name in different territories, as well as if the object has a name that assumes a much wider application.

\section{RESULTS}

The object of the research is the Guryevskiy municipal district, which is located in the very center of the Kemerovo region - Kuzbass, at approximately equal distance $(120-150 \mathrm{~km})$ from the two main cities of the region (Kemerovo and Novokuznetsk), with a combined population of over a million people. This location and transport accessibility give great prospects for the development of microtourism. Part of the district's territory is occupied by the Salair ridge spurs. The nature is picturesque and attractive; caves, waterfalls, lakes of both natural and artificial origin can be of interest for tourists. In addition to natural attractions, there are tourist facilities that are ready to receive residents of Kuzbass and nearby regions - the health resort "Sibirskaya zdravnitsa", the health resort "Lesnoe ozero", the beach recreation area "Salairskie plesy", and the ski resort "Zolotaya gora" [13].

At the first stage of the study, it is necessary to determine the degree of potential interest in microtourism objects in the digital space. For this purpose, search engine query statistics can be used, since the fact of such a query is overwhelmingly characteristic of a user who has not visited the tourist object of interest yet (Table 1).

Table 1. Dynamics of Yandex search queries related to potential interest in recreation in the Kemerovo region Kuzbass and individual microtourism objects of the Guryevskiy municipal district

\begin{tabular}{|c|c|c|c|c|c|c|c|}
\hline Search Query & $\begin{array}{l}\text { July } \\
2018\end{array}$ & $\begin{array}{c}\text { January } \\
2019\end{array}$ & $\begin{array}{l}\text { July } \\
2019\end{array}$ & $\begin{array}{c}\text { January } \\
2020\end{array}$ & $\begin{array}{l}\text { July } \\
2020\end{array}$ & $\begin{array}{c}\text { January } \\
2021\end{array}$ & $\begin{array}{l}\text { July } \\
2021\end{array}$ \\
\hline $\begin{array}{l}\begin{array}{l}\text { Recreation in Kemerovo region } \\
\text { Кемеровской области) }\end{array} \\
\end{array}$ & 5329 & 1153 & 6292 & 1685 & 13207 & 2429 & 12103 \\
\hline Recreation in Kuzbass (rus. отдых в Кузбассе) & 298 & 111 & 403 & 102 & 1428 & 186 & 834 \\
\hline \multicolumn{8}{|c|}{$\begin{array}{ll} & \text { Health resorts } \\
\end{array}$} \\
\hline $\begin{array}{l}\text { Sibirskaya zdravnitsa (rus. Сибирская здравница; eng. } \\
\text { health resort "Sibirskaya zdravnitsa") }\end{array}$ & 265 & 253 & 640 & 775 & 1371 & 1472 & 1710 \\
\hline $\begin{array}{l}\text { Lesnoe ozero health resort Guryevsk (rus. Лесное озеро } \\
\text { санаторий Гурьевск; eng. health resort "Lesnoe ozero" } \\
\text { in Guryevsk) }\end{array}$ & 1120 & 687 & 1068 & 715 & 1126 & 897 & 1570 \\
\hline \multicolumn{8}{|c|}{ Downhill skiing, equipped beaches } \\
\hline $\begin{array}{l}\text { Zolotaya gora Guryevsk (rus. Золотая гора Гурьевск; } \\
\text { eng. ski resort "Zolotaya gora" in Guryevsk) }\end{array}$ & 240 & 2218 & 245 & 2510 & 210 & 1885 & 209 \\
\hline $\begin{array}{l}\text { Salairskie plesy (rus. Салаирские плёсы; eng. beach } \\
\text { recreation area "Salairskie plesy") }\end{array}$ & 4772 & 198 & 7337 & 291 & 1037 & 693 & 12989 \\
\hline \multicolumn{8}{|c|}{ Water bodies, natural attractions } \\
\hline Aprel'ka (rus. Апрелька; eng. Aprel'ka lake) & 2022 & 250 & 3586 & 3045 & 13960 & 3569 & 12547 \\
\hline Lake Aprel'ka (rus. озеро Апрелька; eng. Aprel'ka lake) & 1875 & 133 & 2517 & 294 & 8697 & 358 & 6213 \\
\hline Urskoe lake (rus. Урское озеро; eng, Urskoe lake) & 203 & 5 & 305 & 19 & 567 & 0 & 685 \\
\hline Maslikha (rus. Маслиха; eng. Maslikha country-side) & 70 & 20 & 43 & 798 & 634 & 710 & 740 \\
\hline Maslikha waterfall (rus. Маслихинский водопад) & 0 & 0 & 0 & 0 & 27 & 0 & 40 \\
\hline
\end{tabular}




\begin{tabular}{|c|c|c|c|c|c|c|c|}
\hline Search Query & $\begin{array}{l}\text { July } \\
2018\end{array}$ & $\begin{array}{c}\text { January } \\
2019\end{array}$ & $\begin{array}{l}\text { July } \\
2019\end{array}$ & $\begin{array}{c}\text { January } \\
2020\end{array}$ & $\begin{array}{l}\text { July } \\
2020\end{array}$ & $\begin{array}{c}\text { January } \\
2021\end{array}$ & $\begin{array}{l}\text { July } \\
2021\end{array}$ \\
\hline $\begin{array}{l}\begin{array}{l}\text { Kamenushka } \\
\text { country-side) }\end{array} \\
\text { (rus. Каменушка; eng. Kamenushka }\end{array}$ & 215 & 137 & 485 & 2599 & 3769 & 2527 & 4241 \\
\hline Kamenushka waterfall (rus. Каменушинский водопад) & 0 & 0 & 18 & 0 & 26 & 0 & 27 \\
\hline Waterfall Guryevsk (rus. водопад Гурьевск) & 15 & 0 & 111 & 0 & 234 & 0 & 244 \\
\hline Gavrilovka Caves (rus. Гавриловские пещеры) & 102 & 7 & 87 & 37 & 232 & 46 & 273 \\
\hline \multicolumn{8}{|c|}{ Open-air museums } \\
\hline Shanda (rus. Шанда; eng. open-air museum “Shanda”) & 158 & 120 & 201 & 49 & 37 & 27 & 64 \\
\hline Cholkoy (rus. Чолкой; eng. Cholkoy museum) & 82 & 38 & 52 & 2168 & 436 & 686 & 682 \\
\hline \multicolumn{8}{|c|}{ Sacred sites, temples } \\
\hline $\begin{array}{l}\text { Sacred spring in Salair (rus. Святой источник в } \\
\text { Салаире) }\end{array}$ & 951 & 497 & 921 & 704 & 1337 & 520 & 944 \\
\hline Salair spring (rus. Салаирский источник) & 450 & 562 & 616 & 762 & 720 & 461 & 866 \\
\hline Temple in Salair (rus. Храм в Салаире) & 100 & 58 & 83 & 107 & 117 & 106 & 103 \\
\hline
\end{tabular}

Source: Compiled by the authors

From the data presented in Table 1, we can conclude that for the last three years there has been a significant, multiple increase in potential interest for recreation within the region as a whole, as well as for almost all of the listed microtourism objects. From July 2018 to July 2021, the greatest rise in interest was demonstrated by such objects as the Kamenushka coumtry-side and the Kamenushka Waterfall (more than 20 times growth), health resort "Sibirskaya zdravnitsa" (6.5 times growth), and the Aprel'ka Lake (6 times growth). Besides, the interest in some objects is seasonal by nature.

Next, it is important to determine the real popularity of tourist objects, which may differ significantly from the potential interest at the search stage. As mentioned earlier, not all services provide a comparable analysis of the popularity of objects belonging to different categories. For example, visiting a cave or a waterfall does not involve booking or financial transactions (buying tickets to the destination, entrance tickets, etc.). One of the few universal manifestations of the digital footprint in this case are geolocation tags, or hashtags in social networks, which tourists can equally use both to designate organized objects (hotels, health resorts, museums) and natural attractions. It solves the problem of obtaining comparable data on the scale of microtourism. Table 2 shows the number of posts using hashtags related to the tourist objects of the Guryevskiy municipal district.

Table 2. Number of posts using hashtags related to the tourist objects of the Guryevskiy municipal district in a social network Instagram

\begin{tabular}{|c|c|}
\hline Object & Number of Hashtags as of 31.07.2020 / 31.07.2021 \\
\hline \multicolumn{2}{|c|}{ Health resorts } \\
\hline $\begin{array}{l}\text { Health resort "Sibirskaya zdravnitsa" (rus. санаторий } \\
\text { "Сибирская здравница") }\end{array}$ & \#сибирскаяздравница - 226/228 \\
\hline $\begin{array}{l}\text { Health resort "Lesnoe ozero" (rus. санаторий "Лесное } \\
\text { озеро") }\end{array}$ & $\begin{array}{l}\text { \#лесноеозеро - the hashtag has a much wider application } \\
\text { \#лесноеозерогурьевск - } 33 / 35\end{array}$ \\
\hline Health resort "Borisovskiy" (rus. санаторий “Борисовский”)* & $\begin{array}{l}\text { \#борисовский - the hashtag has a much wider application } \\
\text { \#санаторийборисовский -256/277 }\end{array}$ \\
\hline $\begin{array}{l}\text { Health resort "Kedrovyy bor" (rus. санаторий “Кедровый } \\
\text { бор")* }\end{array}$ & $\begin{array}{l}\text { \#кедровыйбор - the hashtag has a much wider application } \\
\text { \#санаторийкедровыйбор -256/260 } \\
\text { \#кедровыйборкемерово -306/308 }\end{array}$ \\
\hline \multicolumn{2}{|c|}{ Downhill skiing, equipped beaches } \\
\hline $\begin{array}{l}\text { Ski resort "Zolotaya gora" (rus. горнолыжный курорт } \\
\text { "Золотая гора") }\end{array}$ & $\begin{array}{l}\text { \#золотаягора - the hashtag has a much wider application } \\
\text { \#золотаягорагурьевск - 120/229 }\end{array}$ \\
\hline $\begin{array}{l}\text { Beach recreation area "Salairskie plesy" } \\
\text { пляжного отдыха "Салаирские плёсы") }\end{array}$ & $\begin{array}{l}\text { \#салаирскеиплесы - 1900/2200 } \\
\text { \#салаирскиеплёсы - 249/345 }\end{array}$ \\
\hline Ski resort "Tanay" (rus. горнолыжный курорт “Танай”)* & \#танай - 31900/34600 \\
\hline $\begin{array}{l}\text { Taiga health resort "Gornaya Salanga" (rus. таежный } \\
\text { курорт "Горная Саланга")* }\end{array}$ & $\begin{array}{l}\text { \#горнаясаланга - 8100/8800 } \\
\text { \#саланга - 2800/3000 }\end{array}$ \\
\hline Ski resort “Luskus" (rus. горнолыжный курорт “Люскус")* & \#люскус - 3100/3300 \\
\hline \multicolumn{2}{|c|}{ Water bodies, natural attractions } \\
\hline Aprel'ka lake (rus. озеро Апрелька) & $\begin{array}{l}\text { \#апрелька - 2800/3100 } \\
\text { \#озероапрелька - 393/443 }\end{array}$ \\
\hline Urskoe lake (rus. Урское озеро) & $\begin{array}{l}\text { \#урскоеозеро - 12/13 } \\
\text { \#урское - 18/46 }\end{array}$ \\
\hline Maslikha country-side (rus. деревня Маслиха) & $\begin{array}{l}\text { \#маслиха - 117/143 } \\
\text { \#маслихинскийводопад - 3/8 }\end{array}$ \\
\hline Kamenushka country-side (rus. деревня Каменушка) & $\begin{array}{l}\text { \#каменушка - 1400/1600 } \\
\text { \#каменушинскийводопад - 2/11 }\end{array}$ \\
\hline
\end{tabular}




\begin{tabular}{|c|c|}
\hline Object & Number of Hashtags as of 31.07.2020 / 31.07.2021 \\
\hline Gavrilovka Caves (rus. Гавриловские пещеры) & \#гавриловскиепещеры - 37/42 \\
\hline \multicolumn{2}{|c|}{ Open-air museums } \\
\hline $\begin{array}{l}\text { Open-air museum Shanda (rus. музей под открытым } \\
\text { небом “Шанда”) }\end{array}$ & \#шанда -130/192 \\
\hline $\begin{array}{l}\text { Historical and ethnographic museum "Cholkoy" (rus. } \\
\text { историко-этнограффический музей “Чолкой") }\end{array}$ & \#чолкой - 39/65 \\
\hline $\begin{array}{l}\text { Museum-preserve "Tomskaya pisanitsa"'”(rus. музей- } \\
\text { заповедник “Томская писаница") }\end{array}$ & $\begin{array}{l}\text { \#томскаяписаница - 23500/28200 } \\
\text { \#томскаяписанница - 732/789 }\end{array}$ \\
\hline $\begin{array}{lcc}\text { Ecomuseum-preserve “Tyul'berskiy } & \text { gorodok” } & \text { (rus. } \\
\text { экомузей-заповедник “Тюльберский городок”) } & \\
\end{array}$ & \#тюльберскийгородок - 632/713 \\
\hline \multicolumn{2}{|c|}{ Sacred sites, temples } \\
\hline Sacred spring in Salair (rus. Святой источник в Салаире) & $\begin{array}{l}\text { \#святойисточниксалаир - 26/27 } \\
\text { \#салаирскийисточник - 56/117 }\end{array}$ \\
\hline Temple in Salair (rus. Храм в Салаире) & \#салаирскийхрам - 1/1 \\
\hline
\end{tabular}

Source: Compiled by the authors

In contrast to the search query statistics, when determining the number of hashtags, there are currently no opportunities for retrospective analysis - obtaining data for previous periods. Researchers can only get information at the current time (the accumulated number of hashtags), fix it and then compare it with later data, so there are no data before 2020 in the table. When choosing hashtags, it is important to analyze which names consumers use to refer to a particular object - in addition to the generally accepted names, their abbreviated versions can be used (for example, \#шерегеш - \#gesh), or vice versa, more extended versions of the spelling ((\#золотаягора - \#золотаягорагурьевск). It should also be understood that in certain cases a hashtag may have a wider application than the designation of one specific object. For example, tourist sites with the name "Prostokvashino" (camp sites, parks, etc.) exist in dozens of regions of the Russian Federation.

In addition, it is important to note that the analysis of the number of hashtags can be used (as well as the analysis of search queries) to compare competing objects from different territories. So,
Table 2 provides information on health resorts and organized recreation destinations from neighboring municipalities for comparison (marked * in Table 2).

According to Table 2, it can be concluded that the popularity of different tourist objects varies significantly, as do the dynamics of changes in the number of hashtags during the year - for some objects the number of tags increased several times (ski resort "Zolotaya gora", sacred spring in Salair, historical and ethnographic museum "Cholkoy"), while the others remained almost at the same level (health resort "Lesnoe ozero", health resort "Sibirskaya zdravnitsa").

At the third stage of the research, using the data form Tables 1 and 2, the Rating of potential interest (Rpi) and the Rating of real popularity (Rrp) for all the objects included in the population are determined by a simple ranking method on the basis of the indicators values at the definite time moment.

From Table 3, it can be concluded that not in all cases the potential interest to a tourist object coincides with its real popularity.

Table 3. Results of tourist objects ranking by potential interest and real popularity

\begin{tabular}{|c|c|c|}
\hline Object & Rpi & Rrp \\
\hline Health resort "Sibirskaya zdravnitsa" & 4 & 5 \\
\hline Health resort "Lesnoe ozero" & 6 & 12 \\
\hline Ski resort "Zolotaya gora" & 7 & 4 \\
\hline Beach recreation area "Salairskie plesy" & 2 & 2 \\
\hline Aprel'ka lake & 1 & 1 \\
\hline Urskoe lake & 10 & 10 \\
\hline Maslikha country-side & 9 & 7 \\
\hline Kamenushka country-side & 3 & 3 \\
\hline Gavrilovka Caves & 11 & 11 \\
\hline Open-air museum Shanda & 13 & 6 \\
\hline Historical and ethnographic museum "Cholkoy" & 8 & 9 \\
\hline Sacred spring in Salair & 5 & 8 \\
\hline Temple in Salair & 12 & 13 \\
\hline
\end{tabular}

Source: Compiled by the authors

At the fourth stage, based on the ratings obtained, the matrix information model reflecting the correlation between potential interest and real popularity is developed (Figure 1). 
In most cases, the potential interest in tourist objects is converted into real popularity, so when modeling the matrix, the upper-left quadrant and the low-right quadrant are guaranteed to be filled. In the upper-left quadrant, there are leaders with a high degree of interest and high real popularity. These objects have a large and stable tourist flow. They do

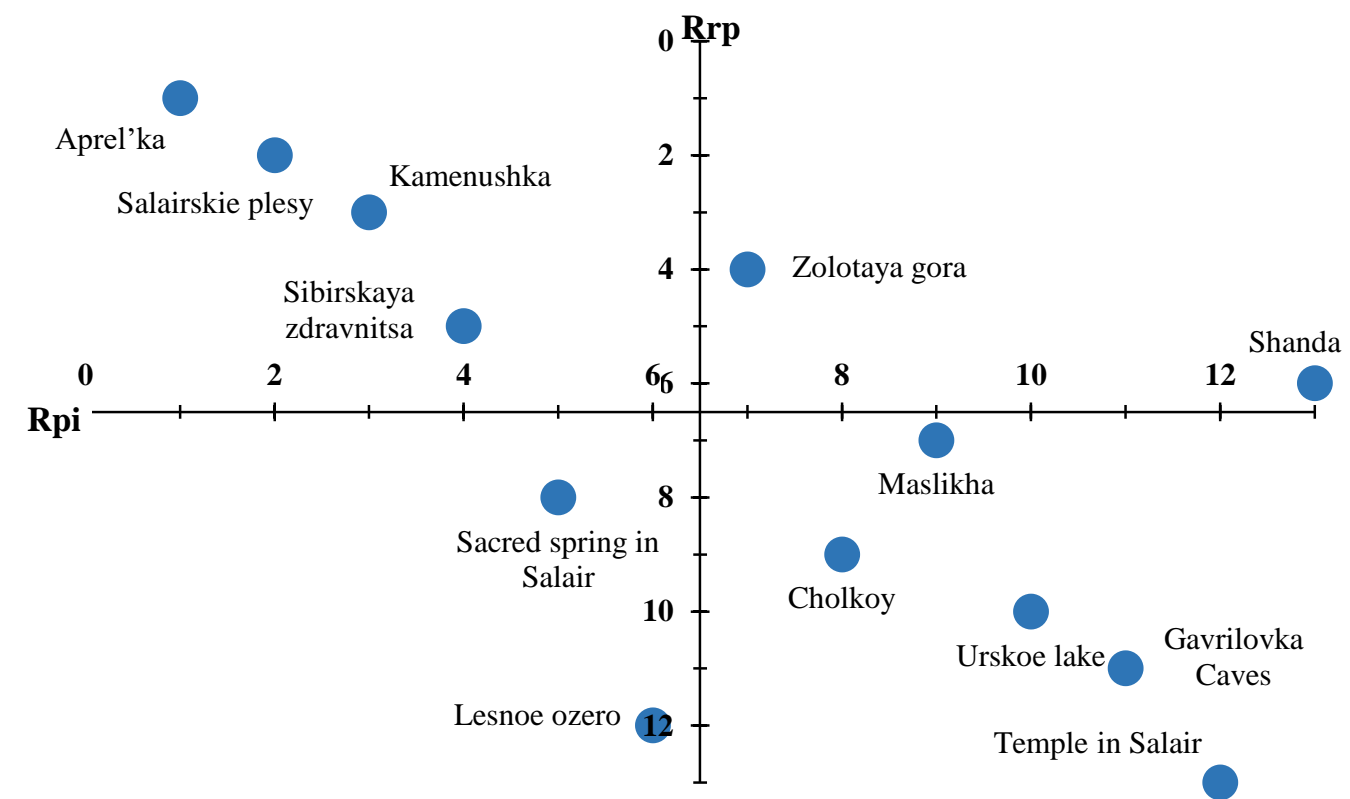

not require active promotion and priority investments. In the low-right quadrant, there are outsiders with low interest and low popularity. The first priority for their development is to organize promotion and increase awareness of potential tourists.

Figure 1. Matrix of correlation between potential interest and real popularity of tourist objects Source: Compiled by the authors

A smaller part of the tourist objects fall into the remaining two quadrants. The low-left quadrant contains the objects with low potential interest but with high real popularity. In most cases, these are either objects with well-organized promotion or long-standing and well-known places that many tourists may have already visited more than once, so search queries are no longer needed.

The objects that fall into the upper-right quadrant deserve the most attention. These are the objects with high potential interest and low real popularity, so-called the "sore spots" of the district. This situation develops when the rating of search queries exceeds the rating of visit tags. It is necessary to investigate the reasons for the current situation, which can include poor transport accessibility of the object, insufficiently developed infrastructure, low level of service, etc. In the given research, the openair museum "Shanda" and the ski resort "Zolotaya gora" are among such objects.

Another tool of assessing the popularity of tourist objects in the digital space, which is not considered in detail in this research, is the analysis of consumer feedback. For example, reviews of the ski resort "Zolotaya gora" are ambiguous, there are many negative assessments of the work activity management, the level of the staff competency, etc., which explains the low real popularity. Tourists, who form search queries, receive controversial information that negatively affects the final decision on visiting this object. Such tourist sites need to increase their competitiveness and eliminate shortcomings, and only after that they can be promoted more actively.

\section{DISCUSSION}

The results of the study were obtained in a logical and consistent way. At the same time, we can talk about the improvement and development of this approach, namely:

- when assessing potential interest, search query statistics from more than one search engine can be used, followed by summing up the figures;

- hashtags on several social networks, including Foursquare and Twitter, can be used when assessing real popularity [12]; 
- it is possible to develop an integrated indicator of real popularity, reflecting not only hashtags, but also geotags, reviews of tourist objects, online travel diary data [11] and other manifestations of the digital footprint.

\section{CONCLUSION}

The proposed tools of digital space analytics and the sequence of their application allow correlating the potential interest in tourist objects and their actual popularity through the use of available open digital space data.

The practical significance of the study is that the given approach to the digital space analytics is universal and can be used to manage the hospitality of any territory, regardless of its specifics and scale. As an advantage for microtourism, it is low-cost, understandable and easy to use for specialists of any training level. The above calculations can be carried out by both tour operators and municipal or regional authorities. The findings of calculations allow predicting tourist flows, allocating investments, identifying groups of objects for priority development and promotion. The prospects for further research within the framework of the stated problem could be to investigate financial flows in the context of individual microtourism objects and their comparison with the potential interest and real popularity of the objects.

\section{AUTHORS' CONTRIBUTIONS}

The authors made an equal contribution to the study: collection and analysis of material; definition of goals and objectives, research methods; formulation and scientific substantiation of conclusions, registration of key research results in the form of an article.

\section{ACKNOWLEDGMENTS}

The authors express their gratitude to the participant of the tourist-reaction cluster $\mathrm{OOO}$ "Health resort "Sibirskaya zdravnitsa" for initiating this research, conducted under the agreement with GAU KO "My Business" as part of an event to organize a range of services and support measures to SMEs in accordance with the State Program of the Kemerovo Region - Kuzbass "Development of small and medium-sized businesses of the Kemerovo Region - Kuzbass for 2014-2024" (approved by Resolution of the Kemerovo Region Administration Board No. 413 dated 01.10.2013).

\section{REFERENCES}

[1] J. Abbas, R. Mubeen, P. Terhemba Iorember, S. Raza, G. Mamirkulova, "Exploring the impact of COVID-19 on tourism: transformational potential and implications for a sustainable recovery of the travel and leisure industry", Current Research in Behavioral Sciences, 2021, vol. 2, p. 100033. DOI: 10.1016/j.crbeha.2021.100033

[2] Z.Yu. Zhelnina, "Potential of digital analytics in studying the phenomenon of micro-tourism", Society: Politics, Economics, Law, 2021, vol. 5, pp. 47-53. (In Russ.). DOI: 10.24158/pep.2021.5.8

[3] J. Chang-Young, Y. Hee-Won, "The structural changes of a local tourism network: comparison of before and after COVID-19", Current Issues in Tourism, 2021, vol. 24, pp. 1-15. DOI: $10.1080 / 13683500.2021 .1874890$

[4] Ph. Everingham, N. Chassagne, "Post COVID19 ecological and social reset: moving away from capitalist growth models towards tourism as Buen Vivir", Tourism Geographies, 2020, vol. 22(3), pp. 555-566. DOI: 10.1080/14616688.2020.1762119

[5] A.A. Zaytsev, R.S. Blizkyi, I.I. Rakhmeeva, N.D. Dmitriev, "Building a model for financial management of digital technologies in the areas of combinatorial effects", Economies, 2021, vol. $9(2), \quad$ p. $52 . \quad$ DOI: 10.3390/economies 9020052

[6] Ju. Reif, D. Schmücker, "Exploring new ways of visitor tracking using big data sources: Opportunities and limits of passive mobile data for tourism", Journal of Destination Marketing \& Management, 2020, vol. 18, p. 100481. DOI: 10.1016/j.jdmm.2020.100481

[7] P. Hatamifar, Z. Ghaderi, L. Ghahramani, "How smartphones enhance local tourism experiences?", Asia Pacific Journal of Tourism Research, 2019, vol. 24, pp. 778-788. DOI: 10.1080/10941665.2019.1630456

[8] H. Purnomo, "Software trends in improving local tourism product marketing in Indonesia: a systematic review", International Journal of Business, Economics \& Management, 2021, vol. 4, pp. 77-84. DOI: 10.31295/ijbem.v4n1.1050

[9] S. Bouguerra, "The role of Facebook in activating local tourism: an analytical study", 
Management \& Economics Research Journal, 2019, vol. 1, pp. 77-86. DOI: 10.48100/merj.v1i3.44

[10] M. Iffan, E. Farida, "The role of internet as a local tourism promotion strategy. Proceedings from INCITEST 2019", in Proceedings of the First IC on Informatics, Engineering, Science and Technology, Bandung, Indonesia, 2019. DOI: 10.4108/eai.18-7-2019.2287748

[11]N. Mou, Y. Zheng, T. Makkonen, N. Yang, J. Tang, Y. Song, “Tourists' digital footprint: The spatial patterns of tourist flows in Qingdao, China”, Tourism Management, 2020, vol. 81, p. 104151.

DOI:

10.1016/j.tourman.2020.104151

[12] M. Salas-Olmedo, B. Moya-Gómez, J. GarcíaPalomares, J. Gutiérrez, "Tourists' digital footprint in cities: Comparing Big Data sources", Tourism Management, 2018, vol. 66, p. 13-25. DOI: 10.1016/j.tourman.2017.11.001

[13] N.V. Dmitrieva, I.V. Sandrakova, "Prospects for the development of intraregional tourism at the municipal level", Economic research and development, 2020, vol. 11, pp. 25-31. (In Russ.). 